\title{
THE AIRPORTS COMMISSION, THE DILEMMAS OF POLITICAL LEADERSHIP AND THE THIRD RUNWAY AT HEATHROW AIRPORT
}

\section{STEVEN GRIGGS AND DAVID HOWARTH}

At the end of October 2016, the Conservative government of Theresa May came out in support of the construction of a third runway at Heathrow airport. In announcing the 'momentous step for our country', Chris Grayling, the Secretary of State for Transport, declared that his government's support for Heathrow expansion 'send[s] a clear message today that Britain is open for business' and 'shows that this is a government unafraid to take the difficult decisions and get on with the job' ${ }^{1}$ At least in political terms, this long-awaited decision seems to suggest that the Airports Commission had successfully completed its task. On the one hand, the launch of the Commission had kept aviation expansion off the national political agenda in the runup to the 2015 election. On the other hand, it had reframed aviation policy by looping public debate back to the issues of connectivity and capacity, and away from earlier preoccupations with climate change and the environmental impacts of air travel, which were especially evident in 2010-2011.

However, the Airports Commission was not successful in generating the 'evidencebased consensus' to which it aspired. ${ }^{2}$ The October decision was not unanimously acclaimed. Conservative MP Zac Goldsmith resigned his Richmond Park seat to fight a by-election as an independent candidate. In the run-up to the announcement, May had also been obliged to loosen the ties of collective responsibility in her cabinet to 
accommodate dissenting voices in the government, including, most notably, Justine Greening, Secretary of State for Education, and Boris Johnson, who was the new Foreign Secretary. Beyond the confines of the House of Commons, local resident groups and campaigners vowed to fight the decision. The Campaign to Protect Rural England dismissed the approval of the third runway as 'madness', while John Stewart, chair of HACAN, the local resident group against Heathrow expansion, claimed that 'real doubts must remain whether this new runway will ever see the light of day. The hurdles it faces remain: costs, noise, air pollution and widespread opposition including an expected legal challenge from the local authorities'. ${ }^{3}$ Thus, although it put airport expansion back on the political agenda, it remains questionable about the extent to which the processes and work of the Airports Commission were able to reframe aviation policy and engineer a broad coalition in support of its new policy settlement.

This article offers an assessment of the character, role and outcomes of the Airports Commission. We begin by analysing its workings from September 2012 until the publication of its final report in July 2015, after which we chart the criticisms of its modus operandi and its final recommendations. Our argument is that the work of the Airports Commission and its attempts to depoliticise aviation through appeals to its 'reasonable' methods and judgements, as well as the character of Howard Davies himself, quickly unravelled once the Commission's final report was released into the public domain, especially when it became clear what its proposals for 'deliver[ing] the maximum connectivity bang for each of our carbon bucks' meant in practice. Indeed, in many ways, public debate soon returned to the perennial arguments and contentions that have dogged aviation expansion since the early 2000s. Ultimately, however, we conclude that the responsibility for this failure does not reside simply at the door of 
the Airports Commission. It rests in failed political leadership and the 'missed opportunity' to build and project a sustainable vision for aviation in the aftermath of the 2010 moratorium on the building of runways in the south-east of England.

\section{THE POLITICAL WORK OF THE AIRPORTS COMMISSION}

At least until the publication of its final report, the Airports Commission appears to have successfully reinforced the conditions for a policy reversal by the Conservative government. Most importantly, it had acted as a catalyst for the provision of ideological cover for the Cameron government, while satisfying the demands of the pro-expansion Heathrow lobby. In itself, this was arguably a programmatic success for the Cameron government, after David Cameron's 'no ifs, no buts' commitment not to expand Heathrow, and the Coalition government's moratorium on new runways in the South-East in May 2010. Of course, the policy reversal in favour of the third runway at Heathrow was undoubtedly made possible by the resignation of Cameron after the referendum decision to leave the European Union (EU) in June 2016, as well as the shifting economic and political priorities that emerged in the post-Brexit period. But, in identifying the challenge facing government to be that of 'balanc[ing] local interests against the wider, longer-term benefits for the $\mathrm{UK}^{, 4}$, the Commission had arguably brought about a governmental reframing of the policy challenges in aviation, which stands in marked opposition to the Coalition government's rejection of aviation expansion in 2010. Indeed, the government's rhetoric after the publication of the Airports Commission harks back to the language of the 2003 Air Transport White Paper and New Labour's expansionist commitments. 
Here the role of Howard Davies and his commissioners was a crucial factor in the depoliticisation of aviation expansion. With the creation of the Commission the issue of airport expansion was transferred into a purportedly neutral domain, where impartial experts and professionals, who were immunised from day to day politics, could resolve the conflicts surrounding the need for additional capacity. In his numerous public interventions, Howard Davies thus employed the rhetoric of science and scientific expertise to try and produce an uncontestable decision, which could form the basis for a rational consensus on the issue. In particular, sophisticated methods of data analysis were employed in an effort to test various options. Figures, tables, graphs, sophisticated methods of statistical analysis, presentations of different scenarios, and so on, were vital parts of the arguments and proposals advanced by the Commission. At the same time, Sir Howard Davies, the chair of the Airports Commission, played on his appeal as a 'reasonable' and 'fair-minded' individual. Indeed, under his able stewardship the Commission sought to privilege open and transparent methods of working, which were grounded on a neutral review of evidence. In short, the character, judgement and reliability of the new body were extolled.

Such rhetorical appeals were reiterated across different policy arenas by the leadership of the pro-expansion campaign. For example, in her opening address to delegates at the Westminster Energy, Environment and Transport Forum at the end of January 2013, Baroness Valentine, chief executive of the pro-expansion lobby, London First, declared that 'we need a rational head to look at the options, which as far as I know, Howard Davies has'.5 Indeed, Valentine's intervention was one amongst many that 
drew attention to the way in which the working methods of the Commission became embodied in the person of Sir Howard Davies. Almost immediately in the media and political circles the Airports Commission became simply the 'Davies Commission'. But equally, through his own performances in meetings and public, the chair of the Commission became associated with a set of dispassionate and reasonable methods for decision-making and public engagement. In fact, even leading opponents of airport expansion praised the manner and knowledge of the Commission's chair.

What is more, as the work of the Commission unfolded, Davies himself appeared to function as a curious symbol of ambiguity in the complex process of seeking a settlement. In other words, his performance of 'reasonable authority', which was independent and could stand above the fray, was able for a time to conceal the differences between the competing demands for expansion, on the one hand, and the desire for environmental protection, on the other, which were being directed at the Commission. In this way, his very persona enabled the displacement of conflict and the de-politicisation of the issue. Indeed, his 'reasoned' practices of authority were juxtaposed with the threat of a return to the 'pub politics' of previous aviation debates. In the aftermath of the 2010 moratorium on airport expansion in the South-East of England, the former Conservative Secretary of State for Transport, Justine Greening, who was (and remains) an emphatic opponent of Heathrow expansion, had described the persistent failures to reach anything more than a temporary settlement in aviation policy from the 2003 Air Transport White Paper onwards as little more than 'pub politics' ${ }^{6}$ 
However, in its public interventions, the Airports Commission persistently returned to the dominant discourses and ideological narratives that have elevated the aviation industry into its powerful position in British society and the UK state. Importantly, it persistently bolstered the existing appeals to economic boosterism through the discourse of connectivity, thereby shifting the underlying economic justifications for expansion on to the hard-to-oppose benefits of international linkages and networks, as well as global competitiveness, and not simply through appeals to the direct economic benefits of airport expansion. Re-articulated through the discourse of connectivity, and the need for a global hub airport to maintain competitiveness, the many economic and social facets of the aviation industry - international trade, global connectivity, hightech manufacturing, tourism, military, aerospace, retailing, and so forth - were thus foregrounded in a political context where the search for economic growth had become an overriding concern for the Coalition government.

Indeed, the Commission made use of the threat of catastrophic economic failure, and lost opportunities, if airport expansion was blocked. Without expansion, the UK would not simply forgo the direct economic benefits of aviation expansion, but would also weaken its global competitiveness, thus losing out to its rivals in emerging markets. Such appeals to the economic benefits of increased connectivity continued to resonate across key sections of the political class, particularly in the shifting context of economic crisis and austerity. According to an Ipsos-Mori poll, which was carried out over June and July 2014, 88 per cent of MPs agreed with the statement that a 'successful hub airport is critical to the UK's future economic success'. 
It is significant that that the work of the Airports Commission also opened up spaces for those actors who operate beyond the state to forge new coalitions in favour of airport expansion, thus providing ideological cover for the Cameron government. Through what we term a 'logic of difference' - splitting demands that have been linked together and then dealing with them in a piecemeal fashion - the Airports Commission had incorporated demands to lower carbon emissions through appeals to emissions trading and capping regimes, as in its final report where it both acknowledged and side-lined the widespread concerns over climate change that had mobilised opposition to expansion under New Labour. Indeed, it had named aviation noise in its interim report as the most significant obstacle to expansion at Heathrow airport, while transforming demands over noise pollution from fears over rising levels of aircraft noise into questions of trust and information.

Such appeals and ways of working were cautiously welcomed and generally endorsed, even by opponents of expansion. Indeed, the final report of the Commission made clear the perceived lack of trust between local residents and airport authorities, put pressure on government to set up a new independent aviation noise authority and community engagement board, banned night flights, and established a package of compensation measures. In other words, Davies had at least recognised some of the grievances and demands of local residents. And this meant that even opponents of the third runway could lay claim to some mini-victories. Equally, Davies and the Commission could legitimately maintain that they had endeavoured to listen to the reasons and arguments against expansion, even if they had not been ultimately convinced by them. 
Supporting such strategies to decontest or depoliticise aviation noise, proponents of expansion- Let Britain Fly and London First - worked at the fringes of the Commission to advocate and construct support for the creation of an independent noise authority, as well as seeking to decouple the issue of noise from that of aviation's carbon emissions. In one significant episode, in March 2014, London First and Let Britain Fly came together with HACAN to co-sponsor the first aviation noise summit, which was addressed by Howard Davies. Leading participants in the noise summit signed a joint public letter demanding that all political parties move towards the early consideration of an independent noise authority. Its rhetoric chimed with that of the Airports Commission, which had called for a 'fresh approach' to 'restore trust and give people the confidence that their legitimate grievances are being addressed' while alluding to the 'common ground' between signatories. ${ }^{7}$

In fact, in the run-up to the 2015 general election, a cross-party consensus on expansion did appear to be forming. At its autumn 2014 party conference, the Liberal Democrat leadership tried unsuccessfully to amend the party's pre-manifesto, which allowed support for a second runway at Gatwick. The decision left the Deputy Prime minister Nick Clegg claiming that 'I just don't think it makes sense to say that you're never going to have a single metre of extra concrete anywhere, in any runway anywhere in the UK'. At the Labour party's autumn conference, Ed Balls, then Shadow Chancellor, reproduced the rhetoric of the pro-expansion campaigners, when he declared that he would put an put an end to 'dither and delay', so that there would be 'no more kicking [aviation] into the long-grass, but taking the right decisions for Britain's long-term future'. And on the day of the publication of the final report, Michael Dugher, Labour's then Shadow Secretary of State for Transport, whilst 
recognising the need for the recommendation of a third runway to meet climate change commitments, was equally concerned in a press release to say 'Labour has always been clear that more airport capacity is vital to Britain's economic success and we need action if we are to maintain our status as Europe's most important aviation hub...[We] must not let politics get in the way of good business - there is too much at stake' ${ }^{8}$

\section{THE UNRAVELLING OF THE AIRPORTS COMMISSION}

The publication of the final report in July 2015 triggered a flurry of attacks designed to discredit the recommendations of the Airports Commission. It was no secret that senior Conservative ministers - Justine Greening, Theresa May, and Philip Hammond, as well as Zac Goldsmith, MP for Richmond, and then London Mayor Boris Johnson all opposed a third runway at the London airport. Echoing his earlier doubts, Johnson described the findings of the Davies Commission as an 'outcome [that] I thought was inevitable because the mandate was to provide a political fig leaf for an establishment U-turn'. For his part, Goldsmith, who had made it know that he would resign and force a by-election if the third runway was to be given the go-ahead, condemned the final report for advancing an 'obsolete' model of aviation. Notably, the owners of Gatwick Airport refused to concede defeat to Heathrow. Stuart Wingate, chief executive of Gatwick, met the final report of the Commission with the claim that 'Gatwick is still very much in the race. The Commission's report makes clear that expansion at Gatwick is deliverable.' 9 
Over the summer of 2015, local residents around Heathrow and anti-expansion groups strived to bring the issue of airport expansion back into the domain of politics, putting political pressure on to David Cameron by drawing public attention to his earlier preelection commitments to a 'no ifs not buts' pledge against expansion at the London airport. On 13 July 2015, 13 activists from Plane Stupid occupied the northern runway at Heathrow Airport for six hours, unfurling banners with 'no third runway, no ifs, no buts'. On the day of the release of the final report, local residents had blocked the Heathrow Airport tunnel. Protests were also undertaken at the Conservative party conference in October 2015, with protesters demonstrating outside conference behind a model plane emblazoned with 'no third runway, no ifs , no buts', and also piping aircraft noises in the early morning to delegates staying in the Midland Hotel. In fact, in this context Cameron's 'no ifs, no buts' slogan began to operate as a point of common opposition, which enabled campaigners to draw equivalences between demands for noise controls, carbon emissions reductions, stronger political leadership and increased corporate regulation, all of which were predicated on the threat of the third runway at Heathrow to local communities and their wellbeing. ${ }^{10}$

Such protests went hand-in-hand with the politicisation of the issue of air quality as campaigners shifted the public terrain of argumentation on to the Commission's analysis of air quality and the capacity of an expanded Heathrow airport to meet EU limits on air pollution. On 24 July, a group of some 6 local council leaders, 8 MPs, environmental pressure groups such as Greenpeace, Friends of the Earth and the Aviation Environment Federation, as well as HACAN and other local resident groups wrote an open letter to the Prime minister arguing that Heathrow expansion would not meet air quality limits and throwing doubt on the consultation on air quality by the 
Airports Commission. The signatories of the letter stated that air quality was not taken 'seriously' by the Commission. They bemoaned the 'exceptional consultation' on air quality undertaken by the Commission which begun on 08 May and ended only three weeks later on 29 May, one month before the publication of the report. Indeed, they threw doubt on the alleged 'open' approach of the Commission, suggesting that the 'Commission effectively treated the consultation as a tick box exercise and one that was immaterial to the overall report. ${ }^{, 11}$

Equally, the Commission's backgrounding of aviation's impact on climate change came under sustained attack. Plane Stupid decried the Davies Commission for having 'completed fudged the climate change implications'. Similarly, James Lees of the Aviation Environment Federation - a leading environmental think tank - condemned the Commission for failing to take full account of aviation's carbon emissions. He suggested that 'Sir Howard's lack of interest in all things climate-related also appears to represent the Airports Commission's approach to this issue'. Typically, such attacks challenged the allegedly rational and reasonable approach of the Commission, and indeed the previous appeals to the reputational power and personal style of Howard Davies. Greenpeace also belittled the environmental case for expansion in the final report, when it asserted that it was so 'riddled with holes that you could fly an Airbus through [it]'. Greenpeace thus challenged the very foundations of the work of the Commission by arguing that the final report exhibited a 'tendency to assume that all sorts of wonderful and unexpected things will happen and relies on this procession of political implausibilities to make the third runway plausible. It is really only one step away from saying "so long as someone solves all the problems, there'll be no problems"", ${ }^{12}$ 
Local residents, councils and environmental groups also moved to attack the character and reputation of Howard Davies by seeking to undermine his legitimacy and capacity to function as a sort of universal symbol of authority, who standing above the political battle could successfully mask over the differences between the competing demands upon the Airports Commission. In July, for example, reports surfaced that the Local Authorities Aircraft Noise Council was considering legal action against the 'biased and flawed' report of the Airports Commission. And in early August, Teddington Action Group threw doubt on the independence of Howard Davies, when they alleged that he worked as a board member of Prudential insurance company, which spent some $£ 300$ million on properties around Heathrow in the run-up to the publication of the final report. By the end of August, local councils in south London were publicly claiming that the Airports Commission 'buried' economic evidence that challenged its forecasts. Gatwick Airport added its voice to these interventions by publishing its own riposte to the findings of the Commission. In an accompanying press release, its Chief Executive argued that 'the final report contains so many omissions and basic errors that its reliability as the basis of aviation policy must be called into question. The findings of this report simply do not add up'. Indeed, such public attacks led Sir Howard Davies to respond formally to the list of charges against the work of the Commission; he not only sought to counter the charges raised by Gatwick, but also opposed those advanced by the London Assembly. ${ }^{13}$

The upshot of this protest was that by the end of the summer, the equivalences that had been constructed, and which had held together the broad coalition that had successfully opposed Labour's proposals for a third runway at Heathrow, were 
quickly being reassembled. In September 2015, there was the launch of the cross-party No Third Runway campaign, while the London Assembly voted against the third runway proposal, and all of the main candidates for the London mayoral elections came out against expansion at Heathrow. In addition, Labour's new leader, Jeremy Corbyn, who had opposed the third runway during his leadership campaign, appointed John McDonnell - a long-time vocal opponent of Heathrow expansion and MP for Hayes and Harlington near the airport - as his shadow chancellor. His appointment, and the election of Corbyn, signalled a change in the approach of the Labour leadership towards the aviation industry. At an October rally against the third runway, for instance, McDonnell publicly condemned the industry, sketching out an alternative narrative in which aviation was once again depicted as a threat to the well-being of local residents and the environment. Indeed, McDonnell amplified attempts to politicise the issue of air quality, informing campaigners that 'in my constituency [...] people are literally dying. They're dying because the air has already been poisoned by the aviation industry. ${ }^{, 14}$

Attacks of this sort gained institutional support from the House of Commons Environmental Audit Committee (EAC). A report published in 2015 attacked the analytical underpinnings of the Airports Commission, and pinpointed limitations within its data, and indeed its interpretation of the data. The EAC here called for the Committee on Climate Change to cast its judgement comment' on the forecasts of the Airports Commission and its policy scenarios, and implored the government to 'act on any recommendations' from this additional scrutiny of the work of the Commission. Once again, its criticisms were particularly strident on the issue of air quality, where it called for the government to: position itself in relation to the Commission's 
interpretation of the Air Quality Directive; demonstrate how its air quality strategy could meet over time legal pollution limits; and to put in place effective monitoring and binding air quality measures for expansion, whilst making clear how it would disaggregate air pollution from transport and from aviation. Significantly, the EAC had been one of the institutional actors that had dismantled the expert and knowledge claims of the 2003 Air Transport White Paper and its discourse of 'sustainable aviation' under New Labour. ${ }^{15}$

Just a week after the publication of its autumn report into the recommendations of the Airports Commission, and as if taking his script from the EAC, Patrick McLoughin, Secretary of State for Transport, announced to Parliament that the government would undertake further studies before coming to a conclusion on the recommendations of the final report of the Airports Commission. McLoughlin repeated that the Cameron government 'accepts the case for expansion', arguing that Commission made a 'strong case for expansion in the south-east'. But, any government decision on expansion was put back until summer 2016. The rationale for this delay was that, after more than 3 years of investigation by the Commission, there was nonetheless a need for further information and clarification. In fact, the government openly acknowledged the EAC's reservations over the impact of airport expansion on air quality, noise mitigation and carbon emissions. Indeed, McLoughlin himself informed Parliament that 'I want to get this decision right. That means getting the environmental response right.' Importantly, the government did not come out in favour of any specific option for expansion, with McLoughlin informing Parliament that 'we are continuing to consider all 3 schemes'. ${ }^{16}$ 
Overall, therefore, some six months after the publication of the Airports

Commission's final report in July 2015, the Conservative government announced what was to become another ten months delay before it came out in support of expansion at Heathrow Airport in October 2016. In a relatively short space of time, and crucially for our analysis, there had been a re-politicisation of aviation policy, which had scuppered the presumption that an 'evidence-based consensus' had emerged from the work of the Airports Commission. In fact, Howard Davies had to publicly defend the Commission's methods of working, while the 'science of airport expansion' - the methods and data analysis underpinning the work of the Commission - was once again being contested by many of the same actors who delegitimised the 2003 Air Transport White Paper. More fully, the Commission's calculations of the impact of rising carbon emissions had been brought into question, as had its calculation of the numbers affected by noise pollution.

Most notably, the alleged misinterpretation of existing air quality regulations in the final report of the Commission, as well as widespread contestation of its analysis into the ability of an expanded Heathrow to meet EU air quality demands, led the government to announce further environmental studies. In short, a strong case can be made that the work of the Airports Commission, especially its efforts to depoliticise aviation policy, had failed by the summer of 2015 , although this is not to dismiss the work of the Commission in underpinning the policy shift of the Conservative government towards expansion. But all such ideological cover evaporated with McLoughlin's acknowledgement of the 'need' for further evidence and studies, as the ball was firmly put back in the court of government; put alternatively, responsibility for decision-making was publicly returned to government and the domain of politics. 
Ironically, after a commission that was supposed to marshal all available evidence for government, the Cameron government delayed any decision under the pretext of seeking further information.

\section{SO CLOSE, YET SO FAR}

As Claus Offe has pointed out, the 'real effects' of any expert committee 'emerge only in the course of conflict-ridden attempts to apply them.' Expert committees thus offer little more than the respite of a 'phoney war', allowing multiple stakeholders to 'prepare themselves for [the] possible trench-warfare' that follows. ${ }^{17}$ Indeed, if we turn to an assessment of the success of the Davies Commission since the publication of its final report a radically different picture emerges. Seen from this perspective, it is hard to refute claims that Davies has failed as a process, in terms of politics, and even in terms of its programmatic outcomes.

Equally, in a short space of time, the political context shifted. The carbon coalition that was successfully forged to oppose the expansion at Heathrow during the last years of New Labour has been reactivated. At the same time, support from the aviation industry has waxed and waned, as Gatwick airport has continued to lobby for expansion, while actively contesting the case for Heathrow. Within the Labour party, the election of Corbyn, and his appointment of McDonnell as Shadow Chancellor, have constrained any opportunities to develop a party leadership consensus on the expansion of Heathrow. In fact, the cabinet remains divided with leading ministers and Conservative party dignitaries opposing expansion at Gatwick and Heathrow. 
The publication of the final report also triggered rival discursive strategies by opponents of expansion at Heathrow airport, who sought to re-politicise the issue and propose alternatives. Such rhetorical operations included efforts to add the issue of air quality and air pollution to the existing terrain of public argumentation; a concerted challenge to the reliability and impartiality of experts and their predictions, as well as the personal reputation of Howard Davies; and the forging of new alliances between groups and campaigns. The latter was accomplished through a persistent repetition of the broken 'no ifs, no buts' promise and by exposing and criticising the dominant 'fantasy narrative' of aviation, which implies that the continued expansion of airport capacity leading to greater economic growth could be seamlessly squared with environmental protections and sustainability.

This 'reality' of the trench warfare to come was in many ways the 'elephant in the room' throughout the work of the Airports Commission. The conflicting reactions to the publication of its interim report at the end of 2013 merely exposed the politicisation that was to follow the publication of its final report in 2015. Indeed, when Howard Davies gave evidence to the Transport Select Committee in January 2014, he was asked to comment on his mission to 'secure an evidence-based consensus', and the dismissal of the interim report by the then Mayor of London, Boris Johnson, who described the report as 'gloppy and tangled, perplexing and odd, and its recommendations to some extent severed from the evidence.' Howard Davies promptly replied: 'Well, he would say that wouldn't he!' ${ }^{18}$ Here, we conclude, are the limits of the Airports Commission as a strategy of depoliticisation. Its creation staved off the trench warfare in order to give the Conservative government the ideological 
cover to reverse its own policy commitments. But in no way did its methods of working and its appeals to evidence transform the preferences of those opposed to expansion. And neither could its exclusionary practices be masked over once the final recommendations were made public. If anything, the conflicts between different airports, between airports and their surrounding communities, between politicians (within and across parties, and among tiers of government), and between many environmental groups and business representatives, have intensified and look certain to continue.

\section{THE DECISION TO EXPAND AS A POLITICAL FAILURE}

Against this background, the May government's support for Heathrow expansion is fraught with difficulties. There is no guarantee of success. How, therefore, should we interpret the legacy of the Airports Commission? And how do we attribute blame for this failure once again to tackle the 'wicked issue' of aviation expansion? As these questions suggest, we situate the work of the Airports Commission within a tangled web of political failures and policy reversals. In the first place, the belated decision to expand Heathrow can be seen as a failure of political and ideological leadership. Before David Cameron became Prime Minister, he made a "no ifs, no buts" promise that there would be no new runway, and the coalition declared a moratorium on expansion in May 2010. But in 2012, after an intense campaign led by business, supporters of Heathrow and London First, the coalition agreed to set up the Airports Commission and thus reopened the case. What is more, the commission's brief was to examine where the new capacity should be - Gatwick, Heathrow or even "Boris 
Island" — rather than whether there should be expansion in the southeast at all. Finally, the aviation industry's demand for more hub capacity (in which an airport is a stepping stone to another destination) made it difficult to argue for spreading expansion across London airports or to regional ones, thus balancing the costs and benefits of expansion.

Secondly, and seen in a longer historical perspective, there has been a failure to recognise that the wrong decision was made in the 1940s to build Heathrow in the first place. Because the airport is in the wrong geographical location, causing noise pollution for the large number of residents who languish under its flight paths, further expansion can only exacerbate its detrimental effects. Indeed, the 2014 Survey of Noise Attitudes, published by the Civil Aviation Authority in February 2017, adds to the concerns over noise pollution. The report demonstrates the increasing annoyance caused by aircraft noise at lower levels than previously recognized, as well as underlining the links between noise annoyance and poor health.

Seen in these terms, the decision to expand Heathrow might be seen as a failure stemming from path dependency and institutional inertia, which goes to the heart of the British state and system of government. This brings to mind the Roskill Commission inquiry of the late 1960s and early 1970s, which was set up to find a location for a third London airport. Roskill's findings were ignored by the government in favour of a different site at Maplin, only for it to abandon that plan when the 1973 oil crisis hit the aviation industry and local MPs threatened to rebel. The upshot has been the dissemination of the "have-your-cake-and-eat-it" narrative that says we can have both airport expansion and environmental protection. In this fantasy, the threat of 
not acting and thus falling behind our foreign competitors is bolstered by the beatific prospect of adding billions to the economy when the new runway is actually built.

A third and critical failure of the new scheme relates to the critical issue of air pollution, which is the cause of major respiratory problems and premature deaths. The problem of meeting legally binding air quality targets in London and surrounding areas was not properly addressed by the Davies Commission, and for that matter by successive governments. Government plans to meet its 2030 air quality targets are highly contested, as the recent court case by legal campaigners, ClientEarth, goes to show. The idea that a reduction of car emissions in and around the airport, for example, will enable expansion plans to meet the required air pollution targets looks wildly optimistic.

Fourthly, and crucially, the plans constitute a failure to tackle climate change. The anti-expansion coalition that successfully challenged New Labour's 2003 Air Transport White Paper put the problem of aircraft emissions and our international commitments to curb climate change at the centre of its campaign. Indeed, in setting out a consultation about airport capacity in 2011, the then Secretary of State for Transport, Philip Hammond, dismissed the previous thinking as "out of date because it fails to give sufficient weight to the challenge of climate change." Yet, once again, environmental considerations have been shoved aside both by the Commission and in the wider public debate that has ensued, particularly within the shifting context of Brexit and the pursuit of new trading links for the UK economy. Signalling such shifting priorities in the foreword to the initial consultation document on the draft Airports National Policy Statement, Chris Grayling, Secretary of State for Transport, 
boldly repeated well-versed claims that 'aviation is a British success story'. He thus framed support for Heathrow expansion in terms of the way in which air travel 'supports economic growth, provides the connections we need to travel and trade, and is at the core of Britain's standing in the global marketplace.'

The initial consultation on the national policy statement closed in May 2017, having amassed some 70, 000 responses. However, it ended with the government's own timetable for a decision over the third runway thrown up in the air by the snap Brexit general election in June 2017. The surprising outcome of the general election, at least for most observers, weakened May's support in the Commons, arguably reinvigorating the Corbyn leadership and its opposition to expansion, while doing little to offset Cabinet divisions on Heathrow. At the same time, it effectively pushed any decision on the third runway at Heathrow back to the spring or summer of 2018. In any case, further delay to any government decision was acknowledged by Grayling, when he announced in September 2017 the need for a new consultation and select committee scrutiny of revised forecasts, noise analysis and air quality plans in response to earlier challenges to government, not least by Client Earth.

This new consultation, which began in October 2017, immediately opened up new opportunities to contest the final report of the Commission. Notably, Zac Goldsmith greeted the publication of the revised draft National Airports Policy Statement with further attacks on the work of the Commission. He pointed out that in the more than two years since the publication of its final report, the context in which the Commission made its recommendations had changed to such an extent that the assumptions underpinning this 'bedrock of the government's decision' had been 
'undermined' by changes to 'data on passenger numbers, on economic benefits and most of all on pollution.' Indeed, Stewart Wingate, the chief executive of Gatwick airport, echoed such concerns, declaring that 'the new information, based on updated forecasts, effectively turns the Airports Commission's work on its head. They completely undermine the basis of the case for expanding Heathrow.' Importantly, in early December 2017, ClientEarth won the right to a new hearing in the High Court for its challenge to the May government's revised air quality plans, with the hearing scheduled to open in February 2018.

In many ways, the May government is confronted with an even more constraining 'rock and a hard place' dilemma than the one which the Davies Commission was designed to resolve, following its establishment in September 2012. It thus continues to face pressures from elements of the business community and the City of London, who wish to expand Heathrow, while carriers such as British Airways and Virgin Atlantic criticize the cost of expansion and the potential rise in landing fees for carriers (Times 09 October 2017). And, as a result partly of its own linkages between Heathrow and Brexit, it cannot insulate debates over expansion from the political uncertainties generated by Brexit negotiations. Indeed, Lord Adonis, former chair of the National Infrastructure Commission, publicly warned that a 'hard Brexit' could scupper any plans for Heathrow expansion (Guardian, 26 June 2017). But, at the same time, local residents, environmental lobbies and direct-action protesters have continued to contest expansion, challenging proposals for new runways at either Heathrow or Gatwick. Significantly, the government's Clean Growth Strategy, which it published in October 2017, appeared to try and respond to these contradictory demands. It suggested that government could still meet the Climate Change Act 
requirement of an 80 per cent reductions in 1990 levels of carbon emissions by 2050 if carbon emissions from aviation rose to $44 \mathrm{MtCO}_{2} \mathrm{e}$, above the $37.5 \mathrm{MtCO}_{2} \mathrm{e}$ advocated by the Committee on Climate Change.

A final and equally telling problem therefore is that in all likelihood the plans will end in another disappointing failure to deliver a mega-infrastructure project on time and within costs. Legal challenges by councils and other affected parties, the precise financing of the proposals (who, for example, will pay for the surface infrastructures needed), coupled with political challenges, will invariably delay the implementation of plans - if they happen at all. At the end of November 2017, the draft New London Plan committed the Mayor of London to oppose expansion at Heathrow 'unless it can be shown that no additional noise or air quality harm would result, and that the benefits of future regulatory and technology improvements would be fairly shared with affected communities.' Indeed, local councils are already preparing to review the decisions and planning procedures in the courts, while local resident groups and direct action campaigners, such as Plane Stupid, are sharpening their preferred tools of protest. We can expect the third runway to become a symbolic battle for environmental campaigners. Heathrow could well end up being the next Notre-Damedes-Landes, the proposed international airport outside Nantes. Plans for this development were resurrected in the early 2000s, having been first mooted in the 1960s and 1970s. However, the French government finally abandoned the project in January 2018 following widespread criticism and protest across the whole of France and Europe. 


\section{CONCLUSION}

Where does this leave us now? In our view, any decision to bring the issue of additional capacity at British airports back onto the political agenda should first have been backed up by the elaboration of a new sustainable vision for maintaining the UK's position in global aviation. Of course, individual airports like Heathrow have sought to develop sustainable visions for the future. For example, the airport published its Heathrow 2.0 plans in February 2017. However, such industry-led visions reproduce the increasingly discredited ideology of 'sustainable aviation', which appeals to technological innovation, better information and dialogue, and the mechanisms of carbon offsetting to legitimise aviation growth while allegedly delivering at the same time environmental protection. As such, they continue to be framed by long-embedded commitments to increase airport capacity, rather than addressing head-on the challenges of climate change, noise pollution and risks to air quality.

An alternative strategy would thus have to step outside this dominant policy frame of threats to airport capacity and then realign airport policy towards demand management and the politics of sufficiency. This would probably involve a strategy that prioritized continuing global aviation links with key trading partners, such as China and the United States, while elaborating creative fiscal solutions to better manage demand for short-haul flights, while also generating new communication technologies and developing alternative transport infrastructures within the UK and Europe. Such an alternative strategywould have delivered on the 2010 commitments to put sustainability before aviation expansion, although it would no doubt have required the 
political acumen to integrate it into a more universal strategy by government and other powerful social forces, and then gain the endorsement of sufficiently large swathes of citizens and the electorate.

Of course, it is true that the removal of Justine Greening from the Department for Transport hampered the development of an alternative image of sustainable aviation. But in the absence of an alternative political vision, the back door was left open for pro-expansionists subtly to reframe the aviation debate around the need to maintain UK's global hub. Here they were helped by the inclusion of aviation in the European Emissions Trading Scheme, which effectively enabled them to side-line environmental concerns over the rising carbon emissions from air travel. When pushed to defend itself against this different angle of attack, the anti-expansion forces were unable to develop a new understanding of aviation in an increasingly competitive and globalized world, though such difficulties applied equally to government, as well as local protesters and environmental campaigners. Starved of the equivalent of an 'integrated transport system' with which to confront pro-expansion forces, and galvanise opposition, the policy stalemate looks likely to persist.

\section{NOTES}

${ }^{1}$ Department for Transport, Government Decides on a New Runway at Heathrow, 25 October 2016, available at www.gov.uk/government/news/government-decides-onnew-runway-at-heathrow accessed 09 March 2017. 
${ }^{2}$ Chair of Transport Select Committee speaking to Howard Davies, January 2014, see www.parliamentlive.tv/Event/Index/83bf7f78-abdd-4ed5-a0d0-29403c8b2d5f accessed 17 March 2016.

${ }^{3}$ Guardian, 25 October 2016.

${ }^{4}$ Department for Transport, Airports Commission Final Report: Oral Statement, Patrick McLoughlin, 01 July 2015, available at www.gov.uk/government/speeches/airports-commission-final-report-oral-statement accessed 10 March 2016.

${ }^{5}$ Valentine, J. 'Opening Remarks' in Westminster Energy, Environment \& Transport Forum, A Fresh Look at UK Airport Capacity: Time for a $3^{\text {rd }}$ Runway at Heathrow? London: Westminster Energy, Environment \& Transport, 31 January 2013, p. 6.

${ }^{6}$ Griggs, S. and Howarth, D. The Politics of Airport Expansion in the United Kingdom, Manchester: Manchester University Press. 2013.

${ }^{7}$ Guardian 10 March 2014.

${ }^{8}$ Guardian, 07 October 2014; London Evening Standard, 22 September 2014;

${ }^{9}$ Guardian, 05 June, 01 July 2015; Independent, 18 April 2015; Observer, 05 July 2015; Telegraph, 01 July 2015; Sky News, 01 July 2015, available at: news.sky.com/story/1511365/residents-vow-to-see-off-heathrow-third-runway accessed 19 October 2015.

${ }^{10}$ Independent, 13 July 2015; Guardian, 01 July 2015; Get West London, 06 October 2015.

${ }^{11}$ Available at: www.wandsworth.gov.uk/news/article/12948/campaigners_take_heathrow_concerns_t o_prime_minister accessed 20 October 2015. 
${ }^{12}$ Lees, J., The Heathrow Noise Sweeteners that Act as a Smokescreen for Third Runway Pollution, 03 July 2015, available at www.aef.org.uk/2015/07/03/theheathrow-noise-sweeteners-that-act-as-a-smokescreen-for-third-runway-pollution/ accessed 09 March 2017; Greenpeace, Davies Fails to Make the Case for a $3^{\text {rd }}$ Runway, G. Thompson, 01 July 2015, available at www.greenpeace.org.uk/blog/climate/davies-fails-make-case-3rd-runway-20150701 accessed 08 March 2017.

${ }^{13}$ Colnbrook Views, 19 July 2015; Guardian, 05 August 2015; Telegraph, 19 August 2015; see also www.wandsworth.gov.uk/news/article/12978/airports_commission_buried_doubts_ov er_heathrow_growth_forecast accessed 20 October 2015.

${ }^{14}$ Independent, 01 August 2015; BBC News, 10 October 2015, available at: www.bbc.co.uk/news/uk-england-london-34495393 accessed 09 March 2017. ${ }^{15}$ House of Commons Environmental Audit Committee, The Airports Commission Report: Carbon Emissions, Air Quality and Noise, HC 389, London: EAC, 2015.

16 Department for Transport, Aviation Capacity. Oral Statement to Parliament, Patrick McLoughlin, 14 December 2015, available at www.gov.uk/government/speeches/aviation-capacity accessed 09 March 2017. ${ }^{17}$ Offe, C. (1984) Contradictions of the Welfare State, edited by J. Keane, London: Hutchinson.

${ }^{18}$ See www.parliamentlive.tv/Event/Index/83bf7f78-abdd-4ed5-a0d0-29403c8b2d5f accessed 17 March 2016. 